\title{
A Case of Pulmonary Hypertension Recurred by Graves' Disease
}

\author{
Jun Seop Lee, Young Sik Choi, Jae Woo Lee, Jin Seok Yoo, Youn Jung Choi, Dong Hyun Park \\ Department of Internal Medicine, College of Medicine, Kosin University, Busan, Korea
}

\section{그레이브스병에 의해 재발한 폐고혈압 1예}

이준섭·최영식·이재우·유진석·최윤정·박동현

고신대학교 의과대학 내과학교실

\begin{abstract}
A few cases of severe pulmonary hypertension with right heart failure associated with Graves' disease were reported in the literature. However, cases of pulmonary hypertension with right heart failure recurred by Graves' disease is very rare. We describe the case of a 60-year old woman who had been treated pulmonary hypertension caused by right pulmonary artery thromboembolism seven years ago. Recently, her pulmonary hypertension with right heart failure was recurred by Graves' disease. The patient's symptoms of pulmonary hypertension was resolved after treatment of Graves' disease.
\end{abstract}

Key Words: Graves' disease, Pulmonary arterial thromboembolism, Pulmonary hypertension

폐고혈압(Pulmonary hypertension)은 안정 시 우심도 자술(right heart catheterization)로 측정한 평균 폐동맥 압이 $25 \mathrm{mmHg}$ 이상으로 증가된 상태로, ${ }^{1}$ 폐동맥 고혈압, 좌심실질환에 의한 폐고혈압, 폐질환과 저산소증에 의한 폐고혈압, 만성 폐색전증(thromboembolism)에 의한 폐 고혈압과 원인 불명 또는 다인성(multifactorial) 기전에 의한 폐고혈압으로 분류된다. ${ }^{2}$ 만성 폐색전증에 의한 폐 고혈압은 폐동맥 혈관 내 혈전 형성과 섬유성 협착 또는 폐동맥 완전 폐색(complete obliteration)에 의해 발생되 는 것으로 폐고혈압의 흔한 원인질환이나, 우심부전으로 생명이 위험할 수 있는 합병증이다. 그레이브스병에 다양 한 심혈관계 질환들이 동반되나, 심한 우심부전을 동반한 폐고혈압은 드물게 발생하며, 국내에서는 2예 보고되어 있다. ${ }^{3,4}$

저자들은 7년 전 급성 폐색전증에 의해 발생한 폐고혈
압 치료 후 항고응제를 투여 중이던 환자에서 최근 발생한 그레이브스병에 의해 폐고혈압이 재발된 1예를 경험하였 기에 문헌고찰과 함께 보고하는 바이다.

\section{증례 보고}

환자: 60세, 여자

주소: 호흡 곤란, 흥부 불편감

현병력: 상기 환자는 7년 전 호흡곤란을 주소로 입원하 였으며 당시 시행한 심초음파 검사에서 우심방과 우심실 의 압력차는 $57 \mathrm{mmHg}$ 이었으며, 흥부 CT에서 우폐동맥 색전증으로 진단되어(Fig. 1A), 본원에서 치료 및 증상 호전으로 퇴원하였다. 퇴원 후 외래를 통하여 지속적으로 항응고제를 투여하며 지내던 중 내원 1개월 전부터 잦은 피로감과 발한 증상이 있었다. 그리고 내원 5일 전부터는 
체위 변화와 관계없이 발생하는 흥부의 불편감과 점차 악화되는 호흡곤란을 주소로 응급실을 방문하였다.

과거력: 7년 전 고혈압 진단 받고 항고혈압제 복용 중이 었다.

가족력: 특이소견은 없었다.

신체검사: 내원 당시 급성 병색을 보이고 있었고, 활력 징후는 혈압 90/60 mmHg, 맥박 68회/분, 호흡수 20회/ 분, 체온은 $36.7{ }^{\circ} \mathrm{C}$ 였다. 두경부에서 안구는 약간 돌출되 어 있었으며, 경정맥의 울혈은 관찰되지 않았다. 갑상선 은 전반적으로 단단하게 커져있었으며 압통은 없었다. 흥부 소견에서 청진상 심박 수는 정상이었고 전수축기 심잡음(holosystolic murmur)이 청진 되었다. 폐호흡음
은 정상이었다. 복부 및 상, 하지에서 특이 소견은 관찰되 지 않았다.

검사실 소견: 말초 혈액 검사에서 백혈구 $6300 / \mathrm{mm}^{3}$, 혈색소 $13.1 \mathrm{~g} / \mathrm{dL}$, 혈소판 $128,000 / \mathrm{mm}^{3}$ 였다. 혈청 생화 학 검사에서 혈중요소질소 $17 \mathrm{mg} / \mathrm{dL}$, 크레아티닌 0.8 $\mathrm{mg} / \mathrm{dL}$, 요산 $6.0 \mathrm{mg} / \mathrm{dL}$, 총단백 $6.2 \mathrm{gm} / \mathrm{dL}$, 알부민 3.6 g/dL, 총빌리루빈 $0.8 \mathrm{mg} / \mathrm{dL}$, AST 23 IU/L, ALT 15 IU/L, Prothrombin time $57.9 \mathrm{sec}, \mathrm{PT}$ (INR) 4.68 (정상 범위, 0.93-1.23), CK-MB 2.60 U/L, Troponin-i 0.05 ng/ml, Pro-BNP(Brain Natriuretic Peptide) 4,833 $\mathrm{pg} / \mathrm{mL}$ 였다. 동맥혈 가스 검사에서 $\mathrm{pH}$ 7.43, $\mathrm{PaO}_{2} 63$ $\mathrm{mmHg}, \mathrm{SaO}_{2} 92 \%$ 였다. 갑상선기능검사에서 $\mathrm{T} 3228.7$
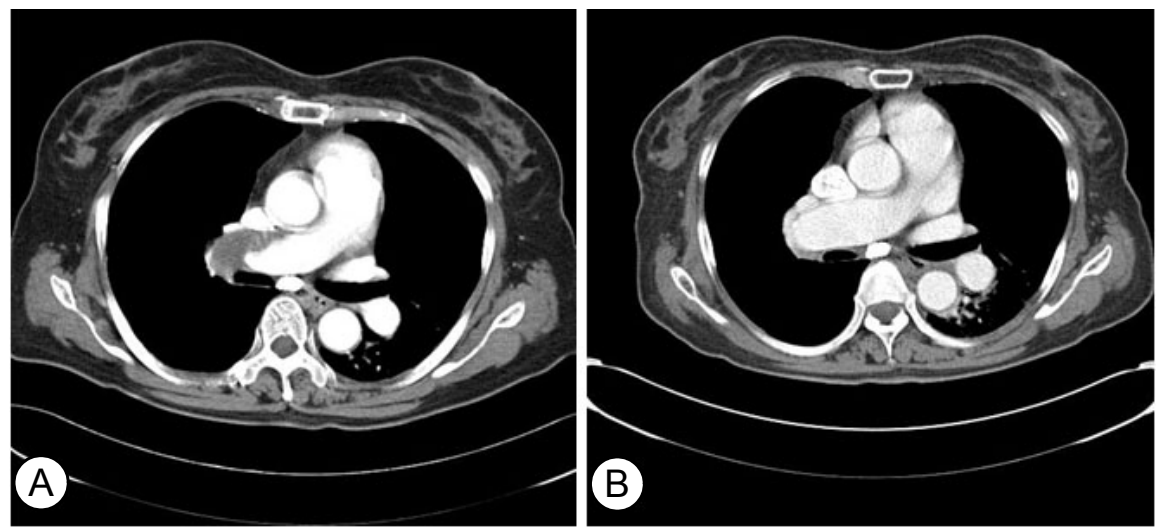

Fig. 1. (A) Huge sized thrombus in right pulmonary artery was showed in chest CT of 7 years before admission, (B) On admission day, chest CT revealed no evidence of pulmonary arterial thrombus.

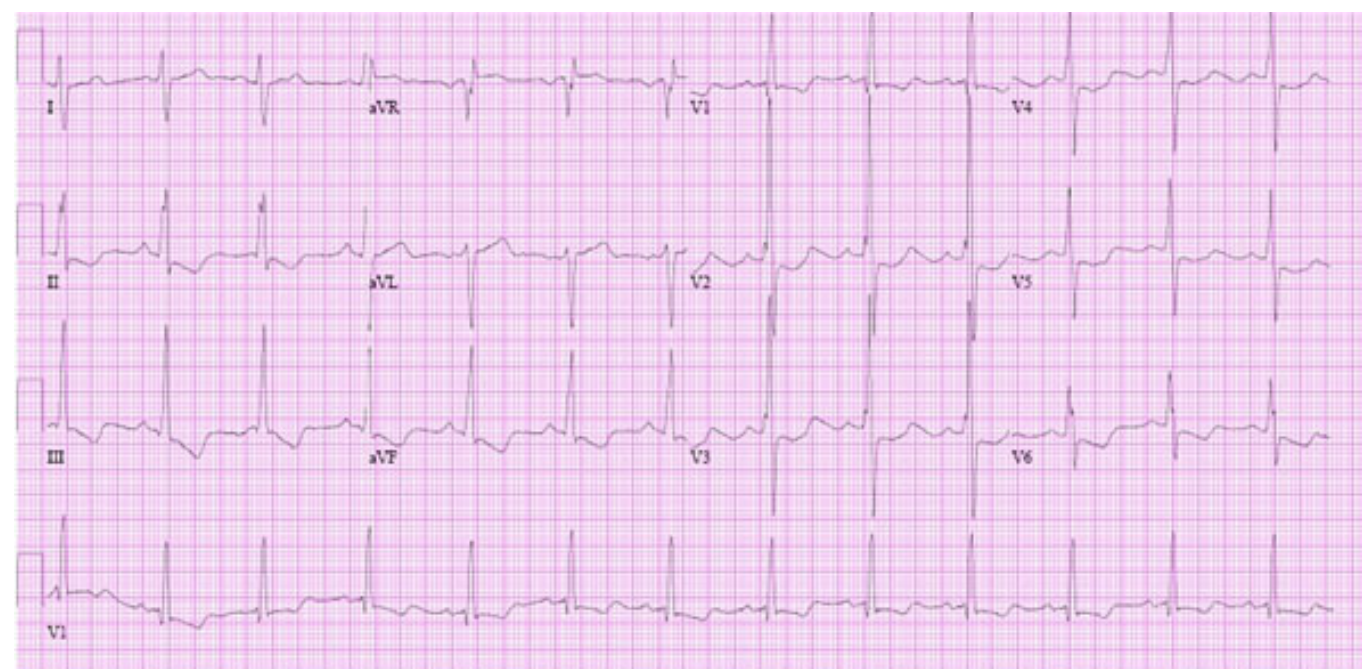

Fig. 2. On admission day, the electrocardiography showed normal sinus rhythm, right ventricular hypertrophy and ST depression in pre-cordial leads. 
$\mathrm{ng} / \mathrm{dL}$ (정상 범위, 60-181), TSH $0.038 \mathrm{mIU} / \mathrm{L}$ (정상 범위, 0.35-5.50), 유리 T4 $1.94 \mathrm{ng} / \mathrm{dL}$ (정상 범위, 0.891.76)였다. 갑상선 자극호르몬 수용체 항체는 $16.8 \mathrm{U} / \mathrm{L}$ (정상 범위, 0-10), 항갑상선 과산화효소항체는 1300.0 $\mathrm{U} / \mathrm{mL}$ (정상 범위, 60 미만), 항갑상선글로불린 항체는 $500.0 \mathrm{U} / \mathrm{mL}$ (정상 범위, 60 미만)의 결과를 보였다.

흥부 X-ray 검사: 경증의 심장 비대 소견이 관찰되었으 며 양 폐야에는 특이 소견이 없었다.

흥부 전산화단층촬영 소견: 환자는 이전에 폐동맥 색전 증이 있어 호흡곤란의 원인이 폐동맥 색전증의 재발 또는 악화로 생각되어 시행한 흥부 CT에서 폐동맥의 혈전은 관찰되지 않았다(Fig. 1B).

심전도 검사: 정상동율동으로 심박 수는 76회/분이었 다. 심전도에서 우심실 비대 소견이 관찰되었으며 전흥부 (pre-cordial leads)에서 ST 분절의 하강 소견 $(1 \mathrm{mmV})$ 이 관찰 되었다(Fig 2).

심초음파 검사: 좌심방 및 좌심실에 비해서 우심방, 우심실의 크기가 증가 되어 있었으며 우심실에 의해서 좌심실이 눌리는(D-shape left ventricle) 양상이 관찰되 었다. 우심방과 우심실의 압력차는 $85.7 \mathrm{mmHg}$ 로 중증 폐동맥 고혈압을 보였다. 좌심실에서 국소적인 벽 운동의 이상은 관찰되지 않았다(Fig. 3).

갑상선초음파 소견: 갑상선 초음파 검사에서는 갑상선 협부 및 양엽의 미만성 종대, 불 균질한 에코 및 과혈관성 (hypervascularity)이 관찰되었다(Fig. 4).

갑상선스캔 소견: $99 \mathrm{mTc}$ 을 이용한 갑상선스캔검사에 서 갑상선에 동위원소의 섭취가 감소되어 있었고, 131I의 24시간 방사성 동위원소 섭취율 $1 \%$ 였다(Fig. 5). 갑상선
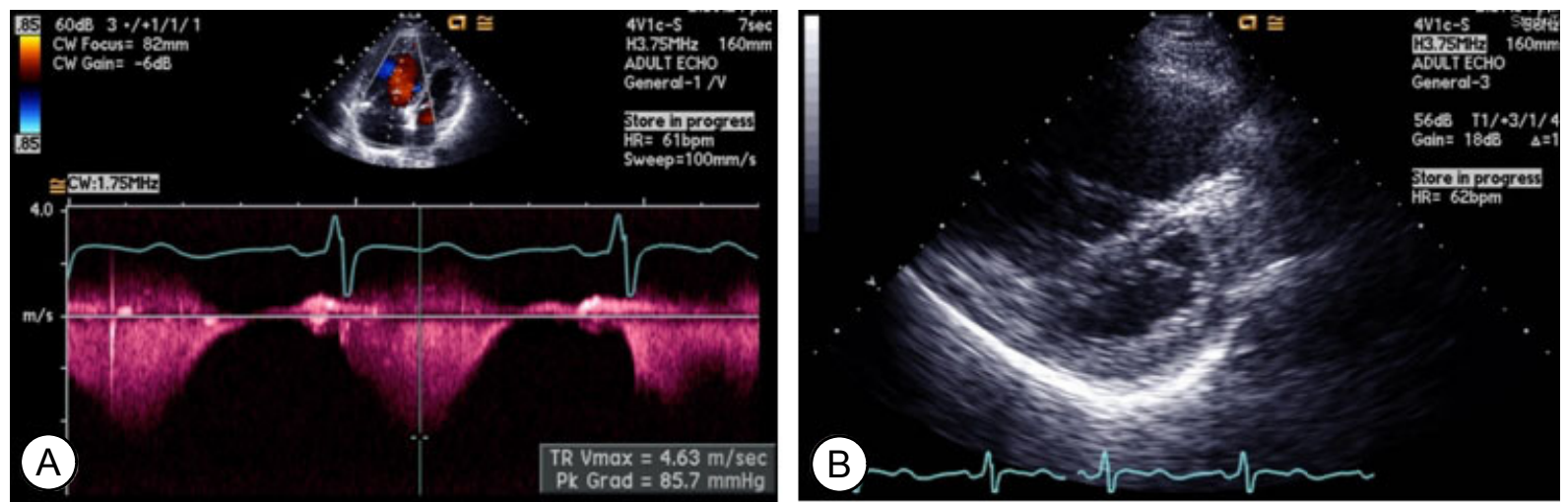

Fig. 3. On admission day, transthoracic-echocardiography revealed severe pulmonary hypertension. (A) Pressure gradient between right atrium and ventricle is $85.7 \mathrm{mmHg}$, (B) Right ventricle is markedly enlarged. Left ventricle showed D-shape appearance.
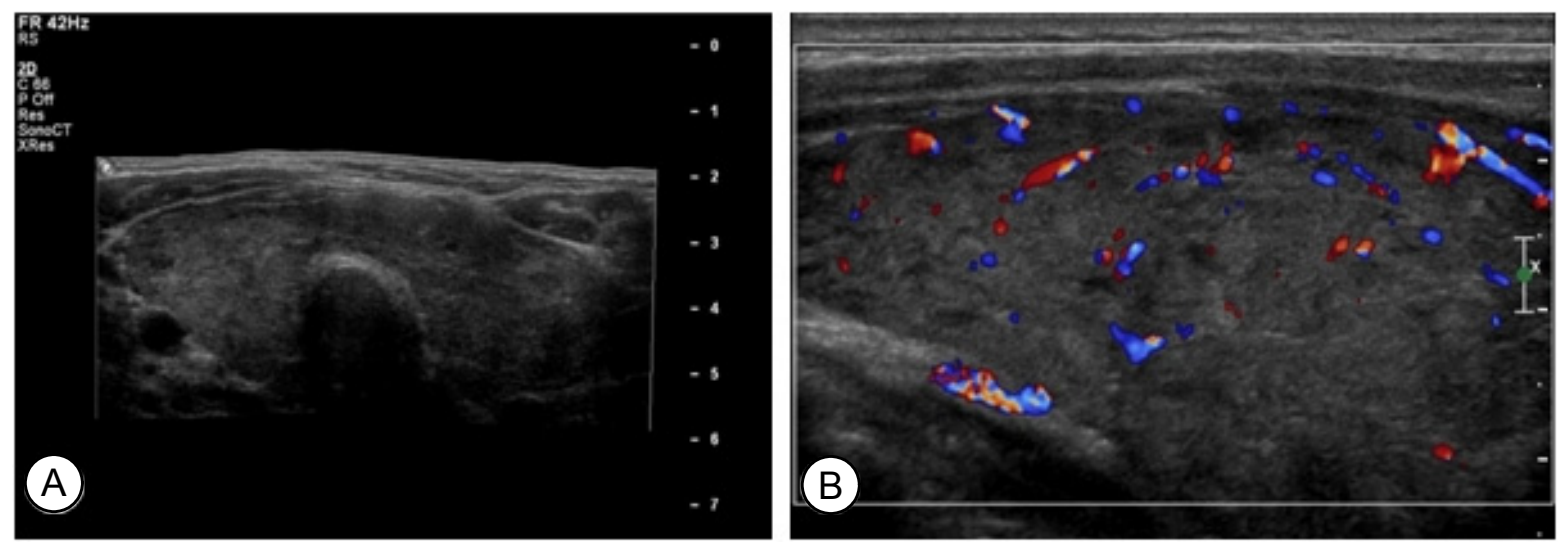

Fig. 4. Ultrasonography of the thyroid. (A) Sonogram showed diffuse enlarged thyroid gland with heterogenous echogenecity (0.92 $\mathrm{cm}$ of isthmus, $2.7 \mathrm{~cm}$ of right lobe, $2.36 \mathrm{~cm}$ of left lobe), (B) Sonogram presented thyroid gland with hypervascularity. 


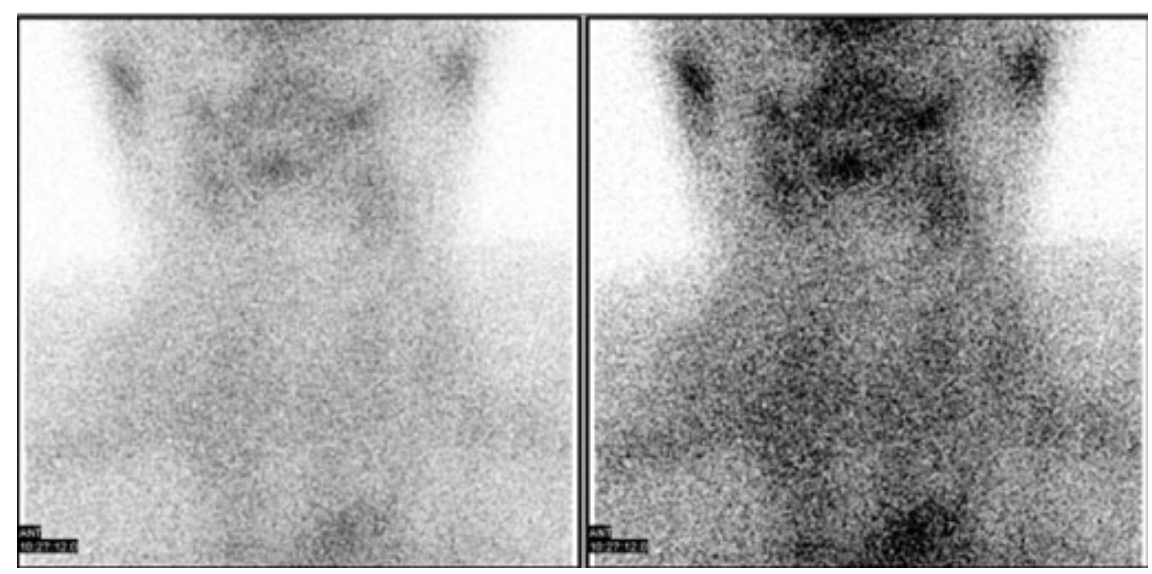

Fig. 5. Non-visualization of both thyroid lobes (I-131 uptake $=1 \%$ ).

기능항진증에서 방사성 동위원소의 섭취율이 감소한 것 은 갑상선스캔 검사를 하기 6일 전 시행한 흥부 전산화단 층촬영 검사에 사용된 조영제(radiocontrast dye)에 의한 것으로 생각된다.

치료 및 임상 경과: 입원 2일째 환자는 심한 호흡 곤란 및 산소 포화도 감소, 혈역학적 불안정으로 중환자실로 옮겨 치료하였다. 심부전에 대한 치료로는 소량의 안지오 텐신전환효소억제제(ACE inhibitor)와 이뇨제를 투여하 였으며, 항갑상선제로 Methimazole $10 \mathrm{mg} / \mathrm{dL}$ 를 투여하 였다. 환자의 심전도상 심박 수는 60회/분이었으며, 심계 항진을 호소하고 있지 않아 베타차단제는 투여하지 않았 다. 입원 5일 후(중환자실 전실 3일 후) 환자의 산소 포화 도 및 혈압은 상승되었으며, 호흡 곤란도 호전되어, 일반 병실로 옮겨졌다. 이후 시행한 폐기능 검사는 정상소견을 보였다. 입원 11일 후 환자의 호흡곤란 정도는 NYHA (New York Heart Association) class II로 호전되었으며, 혈압 및 심박 수 안정 소견 보여서 퇴원하였다. 퇴원 2주 후에는 걸어서 외래 방문하였으며 혈액 검사상 Pro-BNP (Brain Natriuretic Peptide) 1970 pg/mL, T3 71.39 $\mathrm{ng} / \mathrm{dL}$ (정상 범위, 60-181), TSH $1.43 \mathrm{mIU} / \mathrm{L}$ (정상 범위, 0.35-5.50), 유리 T4 $0.83 \mathrm{ng} / \mathrm{dL}$ (정상 범위, 0.89-1.76) 로 호전 소견을 보였다.

\section{고 찰}

폐고혈압은 혈역학적으로 정의하면 모세혈관 전(precapillary) 폐고혈압과 모세혈관 후(post-capillary) 폐고 혈압으로 분류할 수 있다. 모세혈관 전 폐고혈압에는 폐동 맥 고혈압(pulmonary arterial hypertension), 폐질환에 의한 폐고혈압, 만성폐색전증에 의한 폐고혈압과 다인자 성 또는 원인 불명의 폐고혈압이 있고, 모세혈관 후 폐고 혈압에는 좌심질환에 의한 폐고혈압이 있다. 폐동맥 고혈 압과 폐고혈압은 임상증상이나, 검사실 소견이 유사한 점이 많아 실제 혼동하여 사용하는 경우가 많아, 이러한 혼란을 피하기 위해 2008년 미국 Dana Point에서 새로운 분류체계가 제안되어 현재 이용되고 있다. ${ }^{1}$

갑상선 기능 항진증에 의해 나타나는 여러 임상적 특징 들은 갑상선 호르몬 $\mathrm{T} 3$ 에 의한 심장과 심혈관계 효과로 인해 발생한다. T3는 전신혈관의 저항을 감소시키고, 안정 시 심장박동수와 좌심실 구축력과 혈류량을 증가시키고, 심박출량을 증가시킨다. 갑상선 중독증 환자의 $6 \%$ 에서 심부전이 동반되나, 좌심실 수축부전을 동반한 확장성 심 근증은 $1 \%$ 이하에서 이 발생한다고 한다. ${ }^{5}$ 갑상선 기능 항진증에서 좌심부전과 우심부전이 동반되는 경우는 가끔 있으나, 단지 우심부전 만에 의해 임상증상을 동반한 폐고 혈압이 발생하는 경우는 드물다. 본 증례의 경우 심전도와 심초음파 및 pro-BNP (Brain Natriuretic Peptide)의 증 가를 볼 때 중증의 우심부전을 동반한 폐고혈압이었다. 
갑상선 기능 항진증에 동반된 폐고혈압의 원인기전으 로 자가 면역 과정에 의한 내피세포의 손상 및 기능장애, 심박출량 증가에 의한 내피세포 손상과 폐 자체에 존재하 는 혈관확장 물질 대사 증가 등의 여러 가지 기전이 제시되 었으나, 갑상선기능항진증이 자가 면역 질환이며, 자가 항체가 증가되어 있으며, ${ }^{6}$ 또한 다른 자가 면역 질환들이 폐동맥 고혈압을 유발시키는 것을 고려할 때, 자가 면역 기전에 의한 가능성이 가장 높을 것으로 생각된다. 그러나 폐고혈압이 그레이브스병 뿐 아니라 다발성 중독결절에 의해서도 발생하며, 원인은 아직 알려져 있지 않으나 일부 에서는 자가 면역기전에 의해 발생한다고 하고, 또 일부에 서는 자가 면역기전에 대한 것 보다는 갑상선 호르몬에 의한 폐혈류량의 증가에 의해서 발생한다고 한다. ${ }^{7}$

폐고혈압은 안정시 우심도자술(right heart catheterization)로 측정한 평균 폐동맥압이 $25 \mathrm{mmHg}$ 이상으로 증가된 것으로 정의되어 있으나, 심도자술은 침습적인 검사로 검사가 쉽지 않아 임상에서는 주로 비침습적인 심초음파를 활용하고 있다. 심초음파로 측정한 경우폐동 맥 수축기혈압이 $30 \mathrm{mmHg}$, 또는 $35 \mathrm{mmHg}$ 이상을 폐고 혈압으로 정의하고 있으나, 이 경우에는 위양성이 높으며, 폐동맥 수축기 혈압을 $50 \mathrm{mmHg}$ 이상으로 하였을 때 위양 성률을 줄일 수 있다고 한다. ${ }^{1}$ 그레이브스병에서 심초음 파로 측정한 폐동맥 수축기 혈압이 $35 \mathrm{mmHg}$ 이상인 경우 를 폐고혈압으로 진단한 Suk 등의 연구에서 폐고혈압의 유병률은 $44 \%$ 로 높았으나, 모든 환자에서 무증상의 폐고 혈압으로 우심부전 소견을 보인 예는 없었다. 본 증례의 경우 폐동맥의 수축기 혈압은 $85.7 \mathrm{mmHg}$ 로 중증 폐동맥 고혈압을 보였다. 그러므로 임상적으로 의미 있는 폐고혈 압으로 진단하기에는 기준을 상향조정할 필요가 있을 것 으로 생각된다.

심초음파검사 외에 혈액검사로 폐고혈압에 동반된 우 심부전의 평가와 감시(monitoring)에 유용한 생화학적 검사로는 혈청 요산, Atrial Natriuretic Peptide (ANP)와 Brain Natriuretic Peptide (BNP)가 있다. 요산은 허혈성 말초조직에서 손상된 산화적 대사(impaired oxidative metabolism)의 표지자이다. 원발성 폐동맥 고혈압 환자
에서 높은 요산 수치는 불량한 생존율과 연관이 있으나,8 allopurinol을 사용하거나 이뇨제를 사용할 경우에 요산 수치에 영향을 주므로 이를 참고하여 판단하여야 한다. 본 증례의 경우 요산 수치는 $6.0 \mathrm{mg} / \mathrm{dL}$ 였으며, 이뇨제는 사용하고 있지 않았다. ANP와 BNP는 유사한 생리적인 특성을 가지는 물질로서 심근벽의 스트레스에 대한 반응 으로 심근에서 분비되며 혈관확장과 나트륨이뇨(natriuresis)를 유발한다. 이중 BNP는 만성 폐고혈압에 의 한 우심부전의 감시에 유용하다고 한다. BNP 합성 시 생성되는 $\mathrm{N}$-말단분절(NT-proBNP)는 반감기가 길어 혈액순환 중에도 안정성이 높다. 우심부전은 폐동맥 고혈 압에 사망의 주된 원인이며, 혈중 BNP 또는 NT-proBNP 치는 우심부전의 정도를 반영한다고 한다. Nagaya 등 ${ }^{9}$ 은 BNP치의 중앙값인 $150 \mathrm{pg} / \mathrm{mL}$ 을 기준으로 예후를 판단할 수 있다고 하였으며, 치료 3개월 후에 추적 검사한 $\mathrm{BNP}$ 치가 $180 \mathrm{pg} / \mathrm{mL}$ 이상에서 예후가 불량하였다고 한 다. 또한 NT-proBNP는 $1,400 \mathrm{pg} / \mathrm{mL}$ 가 cut-off 수치라 고 한다. Andreassen 등 ${ }^{10}$ 은 모세혈관 전 폐고혈압 환자에 서 NT-proBNP가 $1,400 \mathrm{pg} / \mathrm{mL}$ 이하인 경우는 예후가 양호하였으며, 더 이상 추가적인 치료가 필요하지 않았다 고 한다. 본 증례의 경우 proBNP는 $4,833 \mathrm{pg} / \mathrm{mL}$ 였다.

폐동맥 폐색전증은 폐고혈압의 흔한 원인이며 재발을 방지하기 위해서는 평생 항응고제를 투여해야 한다. 폐색 전증에 의한 폐고혈압의 진단에는 흥부 전산화단층촬영 을 반드시 검사하여야 한다. 본 증례의 경우도 7년 전 폐고혈압 발생 때에는 흥부 전산화단층촬영에서 우폐동 맥에서 색전증이 진단되었으며, 항응고제 투여 중에 호흡 곤란과 우심부전이 발생하여, 폐색전증을 감별하기 위해 흥부 전산화단층촬영을 시행하였으나 정상소견을 보였 다. 그리고 흥부 전산화단층촬영 검사를 위해 사용한 방사 선 조영제에 의해 갑상선 스캔과 24시간 방사성 동위원소 섭취율이 떨어져 파괴성 갑상선염에 의한 갑상선중독증 으로 오진할 수도 있었다.

본 증례를 통하여 갑상선 기능 항진증에 의해 동반된 폐고혈압 중 심초음파에서 발견된 경우는 대부분 무증상 인 경우가 흔하나, 일부에서 심한 우심부전을 일으킬 수 
있으므로 주의를 요하며, 적절한 치료를 시행하면 대부분

회복이 되는 가역적 질환임을 알 수 있었다.

저자들은 7년 전 폐동맥 색전증에 동반된 폐고혈압에 의한 우심부전으로 치료 후 향응고제를 투여해오던 환자 에서 그레이브스병에 의해 폐고혈압이 재발하여 치명적 일 수 있었던 우심부전이 발생한 환자 1 예를 경험하였기 에 문헌고찰과 함께 보고하는 바이다.

\section{참고문헌}

1. Galiè N, Hoeper MM, Humbert M, Torbicki A, Vachiery JL, Barbera JA, et al. Guidelines for the diagnosis and treatment of pulmonary hypertension. Eur Heart J 2009;30:2493-537.

2. Simonneau G, Robbins IM, Beghetti M, Channick RN, Delcroix $\mathrm{M}$, Denton CP, et al. Updated clinical classification of pulmonary hypertension. J Am Coll Cardiol 2009;54:S43-54.

3. Yoon HJ, Jin SW, Jung SJ, Jang SH, Lee JM, Kim JH, et al. A case of hyperthyroidism as a cause of pulmonary hypertension. Korean J Med 2003;65:S773-6.

4. Choi BH, Eom YS, Kim SH, Choi HS, Chung WJ, Lee SH. A case of ascites and extensive abdominal distension caused by reversible pulmonary arterial hypertension associated with Graves'disease. Endocrinol Metab 2011;26:248-52.

5. Klein I, Ojamaa K. Thyroid hormone and the cardiovascular system. N Engl J Med 2001;344:501-9.

6. Chu JW, Kao PN, Faul JL, Doyle RL. High prevalence of autoimmune thyroid disease in pulmonary arterial hypertension. Chest 2002;122:1668-73.

7. Suk JH, Cho KI, Lee SH, Lee HG, Kim SM, Kim TI, et al. Prevalence of echocardiographic criteria for the diagnosis of pulmonary hypertension in patients with Graves' disease: before and after antithyroid treatment. J Endocrinol Invest 2011;34: e229-34.

8. Voelkel MA, Wynne KM, Badesch DB, Groves BM, Voelkel NF. Hyperuricemia in severe pulmonary hypertension. Chest 2000;117:19-24.

9. Nagaya N, Nishikimi T, Uematsu M, Satoh T, Kyotani S, Sakamaki F, et al. Plasma brain natriuretic peptide as a prognostic indicator in patients with primary pulmonary hypertension. Circulation 2000;102:865-70.

10. Andreassen AK, Wergeland R, Simonsen S, Geiran O, Guevara C, Ueland T. N-terminal pro-B-type natriuretic peptide as an indicator of disease severity in a heterogeneous group of patients with chronic precapillary pulmonary hypertension. Am J Cardiol 2006;98:525-9. 